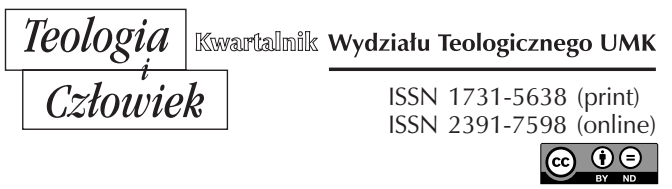

50(2020)2, ss. 123-142

BP ANDRZEJ F. DZIUBA

UNIWERSYTET KARDYNAŁA STEFANA WYSZYŃSKIEGO W WARSZAWIE

REZYDENCJA@DIECEZJA.LOWICZ.PL

ORCID 0000-0002-3845-5364

TERRORYZM - DROGA NEGACJI ŻYCIA

DOI: http://dx.doi.org/10.12775/TiCz.2020.021

Streszczenie. Współczesny świat nadal naznaczony jest wieloma przejawami zła, który przybiera coraz to nowsze formy. Oczywiście nadal istnieją np. działania militarne, sankcje, zbrodnie, zamachy czy zabójstwa. Obecnie tę dramatyczną listę dopełnia terroryzm, który urasta wręcz do znaku współczesnej cywilizacji. To ona udoskonaliła narzędzia i metody przeciwko życiu, solidarności, dobru, sprawiedliwości i pokojowi. Dlatego każdy przejaw terroryzmu wywołuje głęboki ból, przynosi cierpienie, bowiem rani on boleśnie całą cywilizację ludzką. To przejaw barbarzyństwa zawsze i wszędzie zasługujący na powszechne potępienie; jest przeciwko osobie ludzkiej oraz solidarności międzyludzkiej. Ma charakter ekstremistyczny, bowiem jedną z podstaw swego działania przyjmuje absolutyzację interesów politycznych czy ekonomicznych, zgodnie z zasadą „cel uświęca środki”. Terroryzm stanowi prawdziwe przestępstwo przeciw ludzkości.

Słowa kluczowe: terroryzm; życie; zabójstwo; przestępstwo; sprawiedliwość; osoba ludzka.

Abstract. Terrorism - Negation of life. The modern world is still marked by many manifestations of evil, which is always taking on newer forms. There are, for example, military operations, sanctions, crimes, assassinations and killings. Currently, this dramatic list is complemented by terrorism, which has become a sign of modern civilization. These aspects of civilization improve the tools and methods to fight against life, solidarity, against goodness, justice and peace. Therefore, every manifestation 
of terrorism causes deep pain, brings suffering, because it painfully hurts the entire human civilization. This barbarism deserves universal condemnation always and in all circumstances. It works against the human person and interpersonal solidarity. It is of an extremist nature, because one of the foundations of its action is the absolutization of political or economic interests, in accordance with the principle "the end justifies the means". Terrorism is a real crime against humanity.

Keywords: terrorism; life; killing; crime; justice; human person.

Współczesne doświadczenie relacji międzynarodowych, a często i międzypaństwowych czy wreszcie międzyludzkich, naznaczone jest wieloma przejawami zła. Przybiera ono tradycyjne formy, jak np. wojny, sankcje, zbrodnie, zamachy, zabójstwa. W ostatnich latach do tej smutnej, wręcz tragicznej listy dołączył terroryzm. Stał się wręcz znakiem współczesnej cywilizacji, która doszła do perfekcji w udoskonalaniu narzędzi i metod przeciwnych życiu, dobru, sprawiedliwości i pokojowi. To totalny przykład negacji dobra wspólnego, które zdaniem Franciszka „zakłada poszanowanie osoby ludzkiej jako takiej, z jej podstawowymi i niezbywalnymi prawami ukierunkowanymi na jej integralny rozwój"1.

W tym kontekście jakże wymowna była natychmiastowa reakcja Jana Pawła II na atak terrorystyczny w dniu 11 września 2001 roku na wieżowce World Trade Center w Nowym Jorku: „Nie mogę rozpocząć tej audiencji inaczej, jak wyrażając głęboki ból z powodu ataków terrorystycznych, które wczoraj boleśnie zraniły Amerykę i w których tysiące ludzi straciło życie, a bardzo wielu odniosło rany"2.

\section{TERROR CIERPIENIEM}

Szczególną formą przemocy jest terroryzm. Benedykt XVI wskazuje, że

z grubsza można wyróżnić dwa rodzaje nowych form przemocy, które są diametralnie przeciwstawne jeśli chodzi o metody, a także w szczegółach

${ }^{1}$ Franciszek, Encyklika Laudato si, Città del Vaticano 2015, nr 157.

2 Jan Paweł II, Zło i śmierć nie maja ostatniego słowa. Przemówienie podczas audiencji generalnej, Watykan 12.09.2001, „L'Osservatore Romano” 22 (2001) nr 10, s. 66. 
ujawniają duże zróżnicowanie. Przede wszystkim jest to terroryzm, który ucieka się - zamiast do wielkiej wojny - do ataków na konkretne, ważne cele, które mają zniszczyć przeciwnika, bez jakiegokolwiek względu na życie niewinnych ludzi, którzy zostają w okrutny sposób zabici albo zranieni.

Idąc dalej w swojej refleksji, papież dodaje:

W oczach tych, którzy są za to odpowiedzialni, wielka sprawa, jaką jest wyrządzanie szkody nieprzyjacielowi, usprawiedliwia każdą formę okrucieństwa. Negowane jest wszystko, co w prawie międzynarodowym zostało powszechnie uznane i usankcjonowane jako ograniczenie przemocy ${ }^{3}$.

Jest to odrzucenie wszelkich zasad współżycia społecznego i międzynarodowego, wręcz to świadome jego naruszanie i niszczenie. Dochodzi do swoistego wyalienowania ludzkości, przynajmniej jej pewnych części ${ }^{4}$. Jakby niektóre regiony świata są szczególnie ulubionym miejscem aktów terrorystycznych.

Gwałt, przemoc, użycie siły jako moralnie złego narzędzia i środka do wywarcia presji na wolę drugiego człowieka lub społeczności, aby osiągnąć określone cele, stały się dziś chlebem powszednim ludzkości ${ }^{5}$. Chrześcijaństwo zakazuje odwoływania się do dróg nienawiści, zabijania osób bezbronnych, do metod terroryzmu. Negatywna ocena tego rodzaju

${ }^{3}$ Benedykt XVI, Wszyscy jesteśmy odpowiedzialni za sprawę pokoju. Przemówienie w bazylice Matki Bożej Anielskiej w Asyżu, 27.10.2011, „L'Osservatore Romano” 33 (2012) nr 1 s. 28. „Wiemy, że często terroryzm jest uzasadniany względami religijnymi i że właśnie religijny charakter ataków służy za usprawiedliwienie bezlitosnego okrucieństwa tych, którzy wierzą, że mogą pomijać przepisy prawa ze względu na «dobro», do którego dążą. W tym wypadku religia nie służy pokojowi, ale usprawiedliwianiu przemocy" (tamże, s. 28).

4 „Cała ludzkość jest wyalienowana wtedy, gdy powierza się tylko ludzkim projektom, fałszywym ideologiom i utopiom” (Benedykt XVI, Encyklika Caritas in veritate, Città del Vaticano 2009, nr 53).

5 „W ostatnich latach plaga terroryzmu nasiliła się i spowodowała okrutne masakry, które sprawiły, że droga dialogu i negocjacji jest jeszcze bardziej usłana przeszkodami, co rozpala umysły i zaognia problemy, szczególnie na Bliskim Wschodzie" (Jan Paweł II, Zawsze aktualne zadanie: wychowywać do pokoju. Orędzie na Światowy Dzień Pokoju 2004, „L'Osservatore Romano” 25 (2004) nr 2, nr 8). 
przemocy dotyczy każdej jej postaci, która nigdy nie może być ani metodą, ani środkiem w dochodzeniu do rozumianego, choćby tylko subiektywnie, a niekiedy nawet obiektywnie, dobrego celu. Jest ona tym boleśniejsza, gdy znaczona jest śmiertelnymi ofiarami i niewyobrażalnym cierpieniem.

Dotknięcie bezbronnych skrytobójczym terrorem sprzeciwia się wszelkim zasadom relacji międzyludzkich. Dlatego Jan Paweł II przypomina:

Nie można też nie dostrzegać innej bolesnej plagi dzisiejszego świata: zjawiska terroryzmu, nastawionego na zabijanie i niszczenie bez różnicy ludzi i dóbr, na tworzenie klimatu strachu i niepewności, często również poprzez więzienie zakładników. Nawet gdy jako motywację tej nieludzkiej praktyki podaje się jakąś ideologię czy dążenie do stworzenia lepszego świata, akty terroryzmu nigdy nie mogą być usprawiedliwione ${ }^{6}$.

Zresztą to są właśnie typowo ideologiczne motywacje, które z zasady są negacją samej prawdy o człowieku w jego specyfice osobowej oraz wspólnotowej.

Następnie papież jeszcze dodaje ważne rozwinięcie swoich refleksji:

Tym bardziej, gdy - jak to się dzisiaj zdarza - te decyzje i akty, przybierające niekiedy rozmiary prawdziwej masakry, porywanie osób niewinnych i niezamieszanych $\mathrm{w}$ konflikty, mają na celu propagandę własnej sprawy albo też, co gorsze, są celem samym w sobie, gdy zabija się tylko dla zabijania. Wobec takiej grozy i ogromu cierpienia zawsze zachowują swoją ważność słowa, które wypowiedziałem kilka lat temu, a które tu pragnę jeszcze raz powtórzyć: „Chrześcijaństwo zabrania [...] uciekania się do nienawiści, mordowania bezbronnych, do metody terroryzmu"”.

Chrześcijaństwo pozostaje zawsze orędziem pokoju, tolerancji i solidarności, a także miłosierdzia. Jak przypomina papież Franciszek: „Chodzi o to, by być budowniczymi pokoju, ponieważ budowanie pokoju jest sztuką wymagającą pogody ducha, kreatywności, wrażliwości i umiejętności. Rozsiewanie pokoju wokół nas jest świętością" ${ }^{3}$. Sam Jezus

6 Tenże, Encyklika Sollicitudo rei socialis, Città del Vaticano 1987, nr 24.

7 Tamże, nr 24.

${ }^{8}$ Franciszek, Adhortacja apostolska Gaudete et exsultate, Città del Vaticano 2018, nr 89 . 
po zmartwychwstaniu pozdrawia zalęknionych uczniów słowami: „Pokój wam" (J 20,19.21.26) ${ }^{9}$.

Jawi się zatem pytanie, jaki jest cel tych aktów, które sprawiają tak wielkie cierpienie pojedynczym ludziom i różnym środowiskom. Czy istnieje w ogóle cel - więcej: czy może w ogóle istnieć - który by dopuszczał takie działania? Zadawanie cierpienia jest tu jakimś chorobliwym gestem widzenia siebie, egoizmem stanowiącym zaprzeczenie swego człowieczeństwa i powołania ${ }^{10}$. Dlatego dramatycznie woła papież Franciszek: „Nie pozwólmy się okraść z ideału miłości braterskiej!" ${ }^{11}$.

A dalej - trudno znaleźć wyjaśnienie czy wskazanie, z jakich źródeł, z jakich przesłanek, z jakich koncepcji świata bierze początek taki sposób zachowania wobec ludzi. Byłoby trudno, w tym przypadku, mówić o jakiejś jednej ideologii. Czasem próbuje się właśnie w takiej konwencji patrzeć na terroryzm. Tymczasem nie jest on godny nawet tak niskiego wartościowania. Oczywiście, nie wyklucza to ideologii posługujących się terroryzmem czy jego metodami ${ }^{12}$.

9 Por. R. Tremblay, L',innalzamento" del Figlio, fulcro della vita morale, Roma 2001, s. 97-112; R. Schnackenburg, L'esistenza cristiana secondo il Nuovo Testamento, Modena 1971, s. 43-46; J.M. Casabo Suqué, La teología moral en San Juan, Madrid 1970, s. $127-129$.

10 „Już w ubiegłą niedzielę mówiłem o [...] atakach terrorystycznych, które powodują przelew krwi w różnych regionach świata. W zeszły czwartek natomiast doszło do wstrząsającego zamachu w Madrycie, w którym zginęło prawie dwieście osób, a ponad tysiąc zostało rannych. Ta straszliwa zbrodnia wstrząsnęła opinią publiczną na całym świecie. Głęboko poruszeni tak wielkim barbarzyństwem, stawiamy sobie pytanie, jak w ludzkiej duszy mógł się zrodzić pomysł tak potwornych zbrodniczych aktów. Jeszcze raz potępiam te czyny, których nic nie może usprawiedliwić" (Jan Paweł II, Jeszcze raz potępiam terroryzm. Rozważanie przed modlitwa „Anioł Pański”, Watykan 14.03.2004, „L'Osservatore Romano” 25 (2004) nr 6, nr 1-2).

${ }^{11}$ Franciszek, Adhortacja apostolska Evangelii gaudium, Città del Vaticano 2013, nr 101.

12 „Niemniej walka z terroryzmem, aby mogła być zwycięska, nie może ograniczać się jedynie do represji i operacji karnych. Jest bowiem najistotniejsze, aby nawet koniecznemu uciekaniu się do siły towarzyszyła odważna i jasna analiza motywacji, $\mathrm{z}$ jakich rodzą się ataki terrorystyczne. Walka $\mathrm{z}$ terroryzmem winna być prowadzona przede wszystkim na poziomie politycznym i pedagogicznym: $\mathrm{z}$ jednej strony, usuwając przyczyny, które rodzą sytuacje niesprawiedliwości i z których często wypływają decyzje o podjęciu najbardziej desperackich i krwawych aktów; z drugiej, propagując wychowanie 
Terror zawsze prezentuje całkowity brak respektu wobec życia drugiego człowieka. Jednak ostatecznie jest to także brak respektu wobec siebie samego oraz własnego życia. W ten sposób stwarza się swoisty mechanizm tendencji, czy wręcz swoistego wyuzdania dla przemocy, dla destrukcji, dla zabijania. Może to być niekiedy swoista mania, szukająca wszelkich form zniszczenia drugiego człowieka oraz różnych wspólnot i społeczności. Nie wobec życia staje się wręcz swoistym „powołaniem” pielęgnowanym i ożywianym znaczonymi ofiarami i ich krwią, cierpieniem i tragediami ludzi oraz społeczności.

Jan Paweł II w Orędziu na Światowy Dzień Pokoju 2002 przypomina:

Organizacje terrorystyczne, wykorzystujące swych członków jako broń przeciw bezbronnym i przypadkowym osobom, wykazują zatrważający instynkt śmierci, jaki nimi kieruje. Terroryzm rodzi się z nienawiści i powoduje izolację, nieufności i zamknięcie. Przemoc pociąga za sobą dalszą przemoc i tworzy tragiczną spiralę, wciągającą także nowe pokolenia, które w ten sposób dziedziczą nienawiść, jaka dzieliła poprzednie.

Kontynuując tę myśl, papież wskazuje: „Terroryzm bazuje na pogardzie dla ludzkiego życia. Właśnie dlatego nie tylko prowadzi do zbrodni, których nie można tolerować, lecz on sam - używając terroru jako strategii politycznej i ekonomicznej - stanowi prawdziwą zbrodnię przeciw ludzkości" ${ }^{13}$. Ważne jest jasne wskazanie na kwalifikację moralną oraz prawną terroryzmu. Tutaj nie powinno być cienia wątpliwości odnośnie do oceny terrorystów i stosowanych przez nich aktów terroru.

Program i działania, które wybierają śmierć ludzi niewinnych ostatecznie dają świadectwo, że ich nienawistni twórcy oraz ich krwawi wykonawcy nie mają nic do powiedzenia ludziom żyjącym. Ci zaś oczekują

inspirowane szacunkiem dla życia ludzkiego w każdych okolicznościach - jedność rodzaju ludzkiego prawdziwie jest rzeczywistością mocniejszą od przypadkowych różnic, które dzielą ludzi i narody" (Jan Paweł II, Zawsze aktualne zadanie: wychowywać do pokoju. Orędzie na Światowy Dzień Pokoju 2004, nr 8).

13 Tenże, Nie ma pokoju bez sprawiedliwości, nie ma sprawiedliwości bez przebaczenia. Orędzie na Światowy Dzień Pokoju 2002, „L’Osservatore Romano” 23 (2002) $\mathrm{nr} 2, \mathrm{nr} 4$. 
kultury życia, a nie śmierci. Oczekują człowieka z darem człowieczeństwa, ku wzajemnemu ubogaceniu, a nie ku śmierci i zniszczeniu ${ }^{14}$.

Terroryzm nie posiada żadnej prawdy, za pomocą której mógłby odnieść zwycięstwo. Sam z gruntu jest fałszem i kłamstwem. Jego udziałem nie jest prawda, za pomocą której mógłby zyskać serca i sumienia, a w konsekwencji służyć prawdziwemu postępowi i rozwojowi ludzi. Tylko pokój i dobro są pewnym gwarantem i właściwą „bronią” ku przemianie zła i ku zwycięstwu prawdy (por. Rz 12,21) ${ }^{15}$. To sprawia skuteczną przemianę ludzkich serc, stwarzając fundament ku przyszłości ${ }^{16}$.

Ostatecznie przemoc rodzi tylko przemoc. W praktyce jest to już proces wręcz trudny do zatrzymania. Spirala zła jest pokarmem terroryzmu, który jeszcze wzmaga głód przemocy. Krew jest jego napojem, który jednak nie gasi pragnienia czynionego zła, ale wręcz je jeszcze wzmaga, każąc szukać dalszych ofiar.

\section{TERROR PRZECIW OSOBIE}

Terroryzm zostanie w ostateczności zniszczony przez siebie samego, ponieważ w swej nienawiści ślepej i bezsensownej niesie nasienie własnej zagłady, destrukcji. Jednak rzeczywistość tej formy destrukcji nie zwalnia $\mathrm{z}$ osobistego zaangażowania $\mathrm{w}$ podejmowaną walkę $\mathrm{z}$ terrorem, zwłaszcza wyspecjalizowanych osób czy organizacji. Tym niemniej wszyscy współpracując, każdy na własnym poziomie odpowiedzialności, powinni przyczynić się do jego klęski i spełnionego nawrócenia naśladowców terroryzmu. Jest to chrześcijańskie otwarcie ku godności człowieka wynikającej

14 Por. A.F. Dziuba, Kultura życia wobec kultury śmierci, „Collectanea Theologica” 84 (2014), nr 2, s. 93-105.

${ }_{15}$ Por. Franciszek, Adhortacja apostolska Gaudete et exsultate, nr 113.

${ }^{16}$ „Pokój nie może być ustalony za pośrednictwem przemocy. Pokój nie będzie mógł nigdy kwitnąc w atmosferze terroru, zastraszenia i śmierci. Sam Jezus powiedział: «Wszyscy, którzy za miecz chwytają, od miecza giną» (Mt 26,52). Jest to słowo Boga i ono nakazuje temu pokoleniu ludzi gwałtownych wyrzec się nienawiści i przemocy i nawrócić się" (Jan Paweł II, Pokój i pojednanie. Homilia wygłoszona w Drogheda. 29.09.1979, w: Jan Paweł II, Nauczanie papieskie, t. 2, cz. 2, red. E. Weron, A. Jaroch, Poznań 1992, nr 9). 
z jego natury, a więc zakładające realną szansę przemiany i nawrócenia ${ }^{17}$. Zawsze pozostaje nadzieja na zejście z drogi zła, zwłaszcza gdy wsparte jest pomocą innych, ludzi pokoju i dobra.

Żaden przywódca religijny - przypomina Jan Paweł II - nie może zatem być pobłażliwy wobec terroryzmu, a tym bardziej nie może go głosić. Ogłoszenie się terrorystami w imię Boga to profanacja religii. Przemoc terrorystyczna jest zaprzeczeniem wiary w Boga, Stwórcę człowieka, który troszczy się o niego i kocha go. Stoi on w sprzeczności szczególnie z wiarą w Chrystusa Pana, który uczy swych uczniów modlitwy: „Przebacz nam wasze winy, jak i my przebaczamy tym, którzy przeciw nam zawinili” (Mt 6,12) ${ }^{18}$.

Odpuszczenie win bliźnim jest miarą odpuszczenia naszych grzechów przez Boga (por. Mt 6,14-15; Kol 2,14) ${ }^{19}$. Natomiast papież Franciszek przypomniał: „Wiara oświeca również relacje między ludźmi, ponieważ rodzi się z miłości i kieruje się dynamiką miłości Bożej. Godzien zaufania Bóg daje ludziom godne zaufania miasto"20.

Terroryzm wybiera przede wszystkim śmierć człowieka niewinnego. Taka ofiara zdaje się być jedynie godna złożenia na ołtarzu terroru. Może dlatego, że śmierć niewinnych wywołuje największe cierpienie, smutek i ból. Przemoc terroryzmu wybiera śmierć ojca rodziny, naukowca, duchownego,

17 Por. KDK 24; Jan Paweł II, Adhortacja apostolska Reconciliatio et paenitentia, Città del Vaticano 1984, nr 25; tenże, Adhortacja apostolska Christifideles laici, Città del Vaticano 1988, nr 42, 44.

18 Tenże, Nie ma pokoju bez sprawiedliwości, nie ma sprawiedliwości bez przebaczenia. Orędzie na Światowy Dzień Pokoju 2002, nr 7. Por. Benedykt XVI, Encyklika Caritas in veritate, nr 29; J. Ratzinger - Benedykt XVI, Jezus z Nazaretu, cz. 1, Od chrztu w Jordanie do Przemienienia, Kraków 2007, s. 138-140; W. Marchel, Abba, Vater! Die Vaterbotschaft des Neuen Tataments, Düsseldorf 1963, s. 57-67

19 Por. S. Bastianel, L. Di Pinto, Per una fondazione biblica delletica, w: Corso di morale, red. T. Goffi, G. Piana, t. 1, Brescia 1983, s. 141-145; E. Bosetti, Il Figlio e i figli di Dio. Etica filiale del Nuovo Testamento, „Rivista di teologia morale” 36 (2004), s. 227-245; F. Targoński, Morale biblica e teologia morale. Alcuni problemi concernanti lápplicabilità della morale biblica alla teologia morale di oggi, Roma 1982, s. 55-59; P. Guilluy, Pardon et péché, w: Initiation a la pratique de la théologie, red. B. Lauret, F. Refoule, t. 4: Etique, Paris 1984 , s. 268-282.

${ }^{20}$ Franciszek, Encyklika Lumen fidei, Città del Vaticano 2013, nr 50. 
sługi wspólnoty narodowej, strażnika kultury, polityka, promotora dobra wspólnego. Nie ma sfery, która byłaby wyłączona z tego zagrożenia ${ }^{21}$.

Terror jest bezmyślny i zaślepiony w swej pysze czynienia zła, znaczonego śmiercią. Zdaje się nie dopuszczać możliwości innej drogi uzyskania nawet słusznego dobra. Terroryzm narzuca własne, często fundamentalistyczne widzenie prawdy. „Ten kto zabija przez akty terrorystyczne, żywi pogardę dla ludzkości, podchodzi z desperacją do życia i przyszłości - w takiej perspektywie wszystko można znienawidzić i zniszczyć”. Dlatego Jan Paweł II przypomina dalej, że „terrorysta uważa, iż prawda, którą wyznaje, czy cierpienia, jakie przeszedł, mają wartość tak absolutną, że uprawniają go do zareagowania nawet niszczeniem niewinnego życia ludzkiego. Niekiedy terroryzm jest dzieckiem fanatycznego fundamentalizmu, który rodzi się z przekonania, że wszystkim można narzucić własne widzenie prawdy"22. Jest to zatem m.in. negacja pluralistycznej koncepcji rozwoju kultury i cywilizacji ${ }^{23}$.

W tym samym Orędziu z 2002 roku Jan Paweł II jeszcze dodaje: „Tymczasem, nawet jeśli dochodzi się do poznania prawdy - co zachodzi zawsze w sposób ograniczony i niedoskonały - nie można jej nigdy narzucać. Szacunek dla sumienia drugiego człowieka, w którym odbija się obraz samego Boga (por. Rdz 1,26-27), pozwala jedynie zaproponować mu prawdę, do niego zaś należy odpowiedzialnie ją przyjąć”. Zatem papież wyraźnie wskazuje, że „roszczenie sobie prawa do narzucenia innym przemocą tego, co uważa się za prawdę, oznacza pogwałcenie godności człowieka i ostatecznie zniewagę Boga, którego jest on obrazem. Dlatego fundamentalistyczny fanatyzm jest postawą całkowicie sprzeczną z wiarą w Boga. W gruncie rzeczy, terroryzm zinstrumentalizuje nie tylko

21 „Terroryzm jest i zawsze będzie przejawem nieludzkiego okrucieństwa, i właśnie dlatego nigdy nie będzie w stanie rozwiązać konfliktów między ludźmi. Ucisk, zbrojna przemoc i wojna to wybory, które rodzą i pomnażają jedynie nienawiść i śmierć. Tylko rozum i miłość stanowią środki prowadzące do przezwyciężenia i rozwiązywania sporów między osobami i narodami" (Jan Paweł II, Prawda i sprawiedliwość fundamentem wolności i pokoju. Audiencja generalna w pierwsza rocznicę ataku terrorystycznego na USA, Watykan, 11.09.2002, „L'Osservatore Romano” 23 (2002) nr 10-11, nr 2).

${ }^{22}$ Tenże, Nie ma pokoju bez sprawiedliwości, nie ma sprawiedliwości bez przebaczenia. Orędzie na Światowy Dzień Pokoju 2002, nr 6.

${ }^{23}$ Por. Benedykt XVI, Encyklika Caritas in veritate, $\mathrm{nr} 29$. 
człowieka, lecz także Boga, czyniąc z Niego bożka, którym posługuje się do własnych celów"24. Pozostaje jednak aktualne nasuwające się pytanie, dlaczego wybiera cierpienie, zniszczenie i śmierć?

\section{NEGACJA SOLIDARNOŚCl}

Ekstremalne i zgubne wyrażenia przemocy, które mają swe korzenie w faktach zarówno politycznych, jak i ekonomicznych, powiększane są często przez wzajemne oddziaływania ideologii, pochodzące $\mathrm{z}$ zewnątrz i nierzadko wynikające $\mathrm{z}$ upadku fundamentalnych wartości moralnych. Współcześnie bardzo często przemoc ekonomiczna jest bardziej groźna niż polityczna, gdyż ma m.in. szerokie oddziaływanie osobowe i jej skutki rozciągają się bardziej w czasie. Dochodzi jeszcze czynnik zachwiania systemu wartości moralnych, który sprawia zanik istotnych elementów kształtowania postaw osobowych i społecznych. Po prostu zostaje naruszona podstawowa substancja solidarności, odpowiedzialności i dobra wspólnego ${ }^{25}$.

Nawet wtedy kiedy przedkłada się jako motywację terroryzmu tej nieludzkiej praktyki - jakąkolwiek ideologię przemiany ku dobru albo stworzenie lepszej społeczności, akty terroru nie są nigdy usprawiedliwio$n e^{26}$. Oczywiście, nie można tu pominąć długotrwałej tyranii, naruszającej

${ }^{24}$ Jan Paweł II, Nie ma pokoju bez sprawiedliwości, nie ma sprawiedliwości bez przebaczenia. Orędzie na Światowy Dzień Pokoju 2002, nr 6. Por. E. M. Curtis, Image of God, w: The Anchor Bible Dictionary, t. 3, New York 1992, s. 389-391; L.F. Ladaria, Antropologia teologica, Roma - Casale Monferrato 1986, s. 91-95; G. Colzani, Antropologia teologica. L’uomo: paradosso e mistero, Bologna 1997, s. 66-69.

${ }^{25}$ „W trosce o skuteczność chrześcijańskiego świadectwa, [...] trzeba wykonać wielki wysiłek, aby należycie uzasadnić stanowisko Kościoła [...], że [...] interpretuje i chroni wartości zakorzenione $\mathrm{w}$ samej naturze istoty ludzkiej. W ten sposób praktyka miłosierdzia stanie się w konsekwencji także służbą kulturze, polityce, gospodarce i rodzinie, aby wszędzie były przestrzegane podstawowe zasady, od których zależy los człowieka i przyszłość cywilizacji” (Jan Paweł II, List apostolski Novo millennio ineunte, Città del Vaticano 2001, nr 51). Por. A.F. Dziuba, Moralność i polityka. Razem czy oddzielnie?, „Sosnowieckie Studia Teologiczne” 12 (2015), s. 167-192.

26 „Jednakże trzeba wyraźnie stwierdzić, że niesprawiedliwości istniejące na świecie nie mogą być nigdy używane jako usprawiedliwienie zamachów terrorystycznych. Należy też podkreślić, że ofiarami kompletnego zniszczenia ładu, do którego dążą terroryści, padają przede wszystkim miliony ludzi mniej przygotowanych do przetrwania, 
poważnie podstawowe prawa osoby i niebezpiecznie szkodliwej dla dobra wspólnego społeczności ${ }^{27}$. Inne motywy rewolucji czy powstań rodzą tylko nowe niesprawiedliwości, wprowadzają nowe podziały i stają się zachętą do nowych, jeszcze bardziej wyrafinowanych i krwawych aktów terroru.

Oczywiście, jeszcze mniej mogą być zaakceptowane decyzje i gesty, które stają się często prawdziwymi programami znaczonymi krwią i cierpieniem. Jest to tym bardziej bolesne $\mathrm{w}$ wymiarze indywidualnym, gdyż zostanie wykorzystane i nagłośnione przez środki przekazu. W wymiarze zaś społecznym może doprowadzić do paniki czy nawet do zaniechania walki z terroryzmem i innymi formami przemocy.

Niektóre uprowadzenia osób niewinnych i nie zaangażowanych w konflikty, zdają się mieć cel propagandowy, jakim jest odniesienie korzyści we własnej sprawie, często ideologicznej. Nie pyta się tu zazwyczaj o cenę, jaką płacą inni. Brak tu z zasady refleksji, że ideologia jawi się jako niebezpieczeństwo dla życia i zdrowia człowieka, a to już świadczy o jej złu, wykrzywieniach czy stosowanej demagogii.

Jeszcze gorsze są przemoc i terroryzm, które mają cel w sobie samym - zabijać dla samego zabijania. Jest to znak totalnego wyzucia z wszelkich ludzkich reakcji i zaprzeczenie samej istocie życia człowieka, które - w takiej samej wartości - jest także udziałem innych ${ }^{28}$. Zapomina się tu zazwyczaj o możliwości własnej śmierci, a przynajmniej nie widzi się jej w kontekście daru życia, który przewyższa wszelkie inne dary czy naturalne zobowiązania ludzkie.

Dlatego Jan Paweł II przypomina: „Człowiek stał się nieprzyjacielem swego bliźniego. Brat zabija brata. Podobnie jak w pierwszym bratobójstwie, tak i w każdym zabójstwie człowieka zostaje podeptana więź pokrewieństwa "duchowego», która łączy ludzi w jedną wielką rodzinę, jako że wszyscy mają udział w tym samym podstawowym dobru:

jeśli zabraknie międzynarodowej solidarności. Mam na myśli zwłaszcza te rozwijające się kraje świata, które już żyją na granicy przetrwania, a które globalny chaos ekonomiczny i polityczny może ugodzić jeszcze boleśniej. Roszczenie terroryzmu do działania w imieniu ubogich jest z gruntu fałszywe" (Jan Paweł II, Nie ma pokoju bez sprawiedliwości, nie ma sprawiedliwości bez przebaczenia. Orędzie na Światowy Dzień Pokoju 2002, nr 5).

${ }^{27}$ Por. M. Cottret, Zabić tyrana? Tyranobójstwo w nowożytnej Europie, Warszawa 2012, s. 371-386.

${ }^{28}$ Por. Benedykt XVI, Encyklika Caritas in veriatate, nr 29. 
w równej godności osobowej”29. Podkreślając godność osobową człowieka, należy opowiedzieć się za personalistyczną koncepcją życia społecznego, a nawet dążyć do „duchowości komunii” ${ }^{30}$.

Kościół wskazuje, że już „Pismo Święte w opisie zabójstwa Abla przez jego brata Kaina ukazuje od początku historii ludzkości obecność w człowieku gniewu i pożądliwości, skutków grzechu pierworodnego. Człowiek staje się nieprzyjacielem swego bliźniego"31. Oto zabójca staje się nieprzyjacielem swego bliźniego. W Dekalogu znajduje się kategoryczny zakaz zabijania (por. Wj 20,12; Pwt 5,17). Dotyczy to przed wszystkim ochrony życia niewinnego (por. Wj 23,7) ${ }^{32}$.

\section{TO NIE DROGA KU DOBRU}

Trzeba, aby głos totalnego „NIE” wobec terroryzmu usłyszeli ci, którzy świadomie lub nie, wmanipulowani w nieludzką praktykę terroryzmu, wkroczyli na tę straszną drogę negacji życia ${ }^{33}$. Tym przecież jest zabijanie niewinnych albo stosowanie środków krwawego odwetu. Trzeba jednak pamiętać, że taka postawa nie rozwiązuje problemu śmierci i terroru. To po prostu brak bezstronnej oceny ewentualnej rewindykacji, niejednokrotnie zapoczątkowanej przez mniejszości, dla których terroryści pragną działać.

29 Jan Paweł II, Encyklika Evangelium vitae, nr 8.

30 „Pragnę szczególnie poprosić chrześcijan ze wszystkich wspólnot całego świata o świadectwo braterskiej komunii, które stanie się pociągające i oświecające. Oby wszyscy mogli podziwiać, jak troszczycie się jedni o drugich, jak nawzajem dodajecie sobie odwagi i jak sobie towarzyszycie: «Po tym wszyscy poznają, żeście uczniami moimi, jeśli wszyscy będziecie się wzajemnie miłowali» (J 13,35)" (Franciszek, Adhortacja apostolska Evangelii gaudium, nr 99). Por. tenże, Adhortacja apostolska Christus vivit, Città del Vaticano 2019, nr 215; Jan Paweł II, List apostolski Novo millennio ineunte, Città del Vaticano 2001, nr 43; R. Tremblay, „Ma io vi dico...”. L'agire eccellente, specifico della morale cristiana, Bologna 2005, s. 167-184; P. Florenski, La colonna e il fondamento della verità, Milano 1998, s. 518-527; R. Tremblay, Radicati e fondati nel Figlio. Contributo per una morale di tipo filiale, Roma 1997, s. 125-140.

${ }^{31}$ KKK 2259. Por. H. Urs von Balthasar, Antico patto, Milano 1980, s. 146-149; A. Negrier, X. Léon-Dufour, Brat, w: Słownik teologii biblijnej, red. X. Léon-Dufour, Poznań 1973, s. 104-105.

32 Por. Jan Paweł II, Encyklika Evangelium vitae, nr 63.

33 „Terroryzm grozi, rani i zabija wszystkich bez różnicy; jest on w poważnej sprzeczności ze sprawiedliwością i miłością” (KKK 2297). 
Mniejszość pozytywnie pojęta - obojętnie, według jakiego kryterium - ma prawo upomnieć się o należne miejsce w całej zbiorowości ludzkiej. Stosowanie zaś tu przemocy czy terroryzmu wydaje najpierw świadectwo samej mniejszości oraz sprawom, dla osiągnięcia których wybiera się takie a nie inne metody. To uruchamia błędne koło, które w konsekwencji wraca do mocodawców zła, a nie jest w stanie osiągnąć, nawet słusznego prawa czy dobra. Zapewne dlatego Jan Paweł II proroczo woła: „Niech posłuchają mego głosu ci, którzy weszli na nieludzką drogę terroryzmu: ślepe uderzenia, zabijanie niewinnych czy stosowanie krwawego odwetu nie sprzyjają sprawiedliwej ocenie rewindykacji zgłaszanych przez grupy mniejszościowe, na rzecz których oni rzekomo działają"34. Jak każdy terror, to droga donikąd z krwawymi śladami cierpienia i śmierci.

Oczywiście, przemoc może przybierać różne formy czy wyrazy zewnętrzne. Może ona być zwłaszcza fizyczna czy psychiczna. Następnie jest ona ukierunkowana przedmiotowo, strukturalnie czy pośrednio. Jej znamiona są jawne lub ukryte, zamierzone czy też niezamierzone, Bogactwo tych form zdają się narzucać struktury, cele, założenia samego terroru. Dlatego Sobór Watykański II przypomina: „W wielu wypadkach wykorzystanie metod terrorystycznych uchodzi za nowy sposób prowadzenia wojny" ${ }^{35}$. Stąd potrzebne jest, jak podkreśla Benedykt XVI „podjęcie wspólnych zobowiązań, by zapobiec zagrożeniom typu konfliktu wojennego i wykorzenić u podstaw powtarzające się zapędy terrorystyczne" ${ }^{36}$.

Ataki terrorystyczne mogą być łączone $\mathrm{z}$ religią, nawet widziane w perspektywie męczeństwa. W tej perspektywie nauczanie społeczne Kościoła wskazuje jednoznacznie: „Ogłaszanie się terrorystami w imię Boga to profanacja i bluźnierstwo: $\mathrm{w}$ ten sposób instrumentalnie traktuje się nie tylko człowieka, ale również Boga, twierdząc, że posiada się w pełni Jego prawdę, zamiast pozwolić się jej posiąść”. Dlatego mówi dalej nauczanie Kościoła

${ }^{34}$ Jan Paweł II, Poszanowanie mniejszości warunkiem pokoju. Orędzie na Światowy Dzień Pokoju 1989, Città del Vaticano 1988, nr 10. „W słusznym dochodzeniu swoich praw mniejszości mogą dążyć do uzyskania większej autonomii lub nawet niepodległości; w takich delikatnych sytuacjach drogą do osiągnięcia pokoju są dialog i negocjacje. W żadnym wypadku nie można usprawiedliwiać uciekania się do terroryzmu, co może jedynie szkodzić sprawie, której chce się bronić” (KNSK 387).

${ }^{35}$ KDK 79.

${ }^{36}$ Benedykt XVI, Encyklika Caritas in veritate, $\mathrm{nr} 72$. 
nazywanie „męczennikami” tych, którzy giną, przeprowadzając ataki terrorystyczne, jest wypaczaniem pojęcia męczeństwa, które jest świadectwem kogoś, kto pozwala się zabić z tego powodu, że nie wyrzeka się Boga i jego miłości, a nie kogoś, kto zabija w imię Boga. Żadna religia nie może tolerować terroryzmu, a tym bardziej nie może go głosić. Religie angażują się raczej we współpracę w usuwaniu przyczyn terroryzmu i wspieraniu przyjaźni między narodami ${ }^{37}$.

W ten sposób odbiera się religii jej szczególnie ważny element teologiczny. Staje się ona wyłącznie fenomenem wybitnie politycznym. Niekiedy terroryzm jest owocem fundamentalizmu religijnego ${ }^{38}$ czy bardzo złożonych konfliktów międzyreligijnych. Dlatego Benedykt XVI wskazuje, że

wiele świadectw mówiło o poważnych i krwawych konfliktach oraz napięciach utrzymujących się na naszej planecie. Niekiedy walki te zdają się mieć charakter konfliktów międzyreligijnych. Jeszcze raz pragnę powtórzyć, że religia nigdy nie może usprawiedliwiać nietolerancji lub wojen. Nie można zabijać w imię Boga. Wszystkie religie powinny nakłaniać do właściwego używania rozumu i propagować wartości etyczne, kształtujące współżycie społeczne ${ }^{39}$.

To są trudne pytania o możliwości dialogu, który jest jednak trudnym wymaganiem $\mathrm{w}$ relacjach międzyludzkich ${ }^{40}$.

${ }^{37}$ KNSK 515. Por. Jan Paweł II, Nienawiść, fanatyzm i terroryzm znieważaja imię Boga. Spotkanie z przedstawicielami świata kultury, sztuki i nauki, Astana, 24.09.2001, „L'Osservatore Romano” 22 (2001) nr 11-12, s. 24-25.

38 „Istotnie, dzisiaj często się zabija w święte imię Boga, jak wielokrotnie to podkreślał i ubolewał nad tym mój poprzednik Jan Paweł II i ja sam osobiście. Przemoc hamuje autentyczny rozwój i przeszkadza w zmierzaniu narodów do większego dobrobytu społeczno-ekonomicznego i duchowego. Odnosi się to szczególnie do terroryzmu o zabarwieniu fundamentalistycznym, przynoszącym cierpienie, zniszczenie i śmierć, blokującym dialog między narodami i uniemożliwiającym pokojowe i cywilne korzystanie z zasobów. Trzeba jednak dodać, że oprócz fanatyzmu religijnego, który w niektórych sytuacjach uniemożliwia korzystanie z prawa do wolności religijnej, również szerzenie zaprogramowanej obojętności religijnej lub ateizmu praktycznego ze strony wielu krajów, jest sprzeczne z potrzebą rozwoju narodów, gdy z odbiera im energie duchowe i ludzkie" (Benedykt XVI, Encyklika Caritas in veritate, nr 29).

39 Tenże, Adhortacja apostolska Verbum Domini, Città del Vaticano 2010, nr 102.

40 Por. tenże, Encyklika Caritas in veritate, nr 56. 
Wielopłaszczyznowe i różnorodne pochodzenia, przejawy, środki i cele terroryzmu nigdy go nie usprawiedliwiają. Ten rodzaj zła nie może pod żadnymi warunkami, przybrać kształtu dobra ani nie może z niego powstać dobro. Zatem jawi się jasna konieczność odpowiedniej wizji i prezentacji tego fenomenu współczesności, aby nie poddać się szeroko $\mathrm{w}$ nim obecnym manipulacjom ${ }^{41}$. Jest on obecny, choć może czasem wydaje się daleki w sensie czasu czy miejsca występowania, jednak już wówczas jest bardzo groźny.

Podjęta wówczas walka $\mathrm{z}$ nim winna być wspierana przez wszystkich, świadomych odpowiedzialności za wielkie dobro ludzkości i świata w pokojowej koegzystencji. „Jeżeli jednak, przypomina Kościół, środki bezkrwawe wystarczają do obrony i zachowania bezpieczeństwa osób przed napastnikiem, władza powinna ograniczyć się do tych środków, ponieważ są bardziej zgodne z konkretnymi uwarunkowaniami dobra wspólnego i bardziej odpowiadają godności osoby ludzkiej”², ale nie może jednocześnie naruszać zasady państwa prawa ${ }^{43}$.

${ }^{41}$ „To właśnie pokój, oparty na sprawiedliwości i przebaczeniu, atakowany jest dzisiaj przez międzynarodowy terroryzm. W ostatnich latach, szczególnie po zakończeniu zimnej wojny, terroryzm przemienił się w wyrafinowany system zależności politycznych, technologicznych i ekonomicznych, który przekracza granice krajów i rozszerza się na cały świat. Są to prawdziwe organizacje, często mające do dyspozycji ogromne kapitały, opracowujące szeroko zakrojone strategie, które godzą w niewinne osoby, nie mające nic wspólnego z celami terrorystów" (Jan Paweł II, Nie ma pokoju bez sprawiedliwości, nie ma sprawiedliwości bez przebaczenia. Orędzie na Światowy Dzień Pokoju 2002, nr 4).

${ }^{42}$ KKK 2267. „Istnieje zatem prawo do obrony przed terroryzmem. Jest to prawo, które - jak wszystkie inne - powinno odpowiadać zasadom moralnym i prawnym zarówno w wyborze celów, jak i środków. Wskazywanie winnych musi być oparte na niepodważalnych dowodach, ponieważ odpowiedzialność prawna jest zawsze osobista, nie wolno jej zatem rozszerzać na narody, grupy etniczne czy religijne, do których należą terroryści. Współpraca międzynarodowa $\mathrm{w}$ walce $\mathrm{z}$ działalnością terrorystyczną winna też wiązać się ze szczególnym wysiłkiem politycznym, dyplomatycznym i ekonomicznym, ażeby z odwagą i determinacją przezwyciężać istniejące sytuacje ucisku i izolacji, które mogą być podłożem programów terrorystycznych. Łatwiej bowiem werbować terrorystów w kontekście społecznym, w którym łamie się prawa i zbyt długo toleruje niesprawiedliwość" (Jan Paweł II, Nie ma pokoju bez sprawiedliwości, nie ma sprawiedliwości bez przebaczenia. Orędzie na Światowy Dzień Pokoju 2002, nr 5).

${ }^{43}$ „W koniecznej walce $\mathrm{z}$ terroryzmem prawo międzynarodowe staje dziś wobec zadania wypracowania właściwych środków prawnych i skutecznych mechanizmów za- 
Wreszcie, należy negatywnie ocenić samo zaangażowanie w terroryzm - czy to indywidualne czy wspólnotowe. Chrześcijaństwo, jako że dąży do realnego dobra, pokoju i sprawiedliwości, winno tu odegrać szczególnie pozytywną rolę. Dlatego Benedykt XVI wskazuje: „W perspektywie odpowiedzialności społecznej wszystkich chrześcijan, Ojcowie synodalni przypomnieli, że ofiara Chrystusa jest tajemnicą wyzwolenia, która nas przynagla i ciągle prowokuje”. W konsekwencji papież formułuje apel:

Zwracam się więc z apelem do wszystkich wiernych, by rzeczywiście działali na rzecz pokoju i sprawiedliwości: „Kto zaś uczestniczy w Eucharystii, powinien angażować się $\mathrm{w}$ budowanie pokoju w naszym świecie, naznaczonym przemocą i licznymi wojnami, a dziś w szczególny sposób przez terroryzm, korupcję ekonomiczną oraz wykorzystywanie seksualne" ${ }^{\prime 4}$.

Wymowne jest przywołanie razem tych trzech dramatycznych kategorii zła. Na to zwraca uwagę także papież Franciszek w Christus vivit ${ }^{45}$. Dalej Benedykt XVI naucza bardzo konsekwentnie:

Wszystkie te problemy rodzą z kolei inne upokarzające zjawiska, budzące żywe zaniepokojenie. Wiemy, że nie można stawiać czoła tym sytuacjom w sposób powierzchowny. Właśnie na mocy tajemnicy, którą celebrujemy, trzeba demaskować okoliczności sprzeciwiające się godności człowieka, dla którego Chrystus przelał swoją krew, potwierdzając w ten sposób ogromną wartość każdej pojedynczej osoby ${ }^{46}$.

pobiegania, kontroli i karania przestępstw. W każdym przypadku demokratyczne rządy dobrze wiedzą, że użycie siły przeciw terrorystom nie może usprawiedliwiać odejścia od zasad państwa prawa. Decyzje polityczne, które miałyby przynieść sukces, nie biorąc pod uwagę podstawowych praw ludzkich, byłyby nie do przyjęcia, gdyż cel nie uświęca środków" (tenże, Zawsze aktualne zadanie: wychowywać do pokoju. Orędzie na Światowy Dzień Pokoju 2004, nr 8).

${ }^{44}$ Benedykt XVI, Adhortacja apostolska Sacramentum caritatis, Città del Vaticano 2007, $\mathrm{nr} 89$.

${ }^{45}$ Por. Franciszek, Adhortacja apostolska Christus vivit, nr 98.

${ }^{46}$ Benedykt XVI, Adhortacja apostolska Sacramentum caritatis, nr 89. Por. A.F. Dziuba, Paschalne obdarowanie Duchem Świętym, „Studia Gnesnensia” 28 (2014), s. 91-106. 
Przecież „Chrystus zjednoczył się jakoś z każdym człowiekiem”"47, ku jego ziemskiej odnowie i perspektywie wieczności.

Zaangażowanie na rzecz pokonania zła winno ostatecznie wydać owoce w postaci solidarności międzyludzkiej i międzyosobowej.

Żywimy głębokie przekonanie - jak naucza Jan Paweł II w swej pierwszej encyklice Redemptor hominis - że nie ma takiego programu w dzisiejszym świecie, w którym nawet na gruncie przeciwstawnych sobie światopoglądów nie wysuwa się zawsze człowieka na pierwszy plan. Jeśli przeto pomimo takich założeń prawa człowieka bywają na różny sposób gwałcone, jeśli w praktyce jesteśmy świadkami [...] gwałtów, tortur, terroryzmu, a także różnorodnych dyskryminacji, to musi to być konsekwencją innych przesłanek, które podkopują, a często niejako unicestwiają skuteczność humanistycznych założeń owych współczesnych programów i systemów. Nasuwa się wniosek o konieczności poddawania tychże stałej rewizji właśnie pod kątem obiektywnych i nienaruszalnych praw człowieka ${ }^{48}$.

Współcześnie występują także koncepcje „humanizmu”, które faktycznie prowadzą do poniżenia i unicestwienia człowieka ${ }^{49}$.

Jan Paweł II w Orędziu 1986 roku ukazuje, że ludzkość musi nauczyć się pokoju, dialogu, umiejętnego argumentowania swoich praw, szukania właściwych rozwiązań.

W duchu solidarności i przy pomocy dialogu nauczymy się: a) szacunku dla każdej osoby ludzkiej; b) szacunku dla prawdziwych wartości i kultury innych; c) szacunku dla słusznej autonomii i prawa innych do samostanowienia; d) przezwyciężania własnego egoizmu, aby zrozumieć i popierać dobro innych; e) włączania własnych środków w rozwoju solidarności społecznej dla postępu i rozwoju, płynących z równości i sprawiedliwości;

47 Jan Paweł II, Encyklika Redemptor hominis, Città del Vaticano 1979, nr 13. Por. Franciszek, Adhortacja apostolska Christus vivit, nr 118-120.

${ }^{48}$ Jan Paweł II, Encyklika Redemptor hominis, nr 17.

49 Por. tenże, Adhortacja apostolska Christifideles laici, nr 5. „Humanizm wykluczający Boga jest humanizmem nieludzkim. Jedynie humanizm otwarty na Absolut może nam przewodzić w krzewieniu i realizacji form życia społecznego i obywatelskiego - w obrębie struktur, instytucji, kultury i etosu - ratując nas przed ryzykiem, że staniemy się zakładnikami przelotnej mody" (Benedykt XVI, Encyklika Veritas in caritate, nr 78). 
f) budowania struktur, które sprawią, że społeczna solidarność i dialog będą trwałymi znamionami świata, w którym żyjemy ${ }^{50}$.

Natomiast papież Franciszek przypomina: „Kościół głosi «dobrą nowinę o pokoju» (Ef 6,15) i jest otwarty na współpracę z wszystkimi władzami krajowymi i międzynarodowymi, by troszczyć się o dobro uniwersalne" ${ }^{\prime 1}$.

Terroryzm jest przejawem barbarzyństwa i zawsze i w każdych okolicznościach jest czynem niemoralnym, zasługującym na potępienie. Ma charakter ekstremistyczny, gdyż za podstawę swych działań przyjmuje absolutyzację interesów politycznych czy ekonomicznych zgodnie z zasadą „cel uświęca środki”. Terroryzm stanowi prawdziwe przestępstwo przeciw ludzkości.

Wobec terroryzmu Leszek Kołakowski wymownie pyta:

Najgłupszym sposobem reagowania na to, co się stało 11 września, jest powiedzenie, ogłaszane czasem z miną melancholijnego mędrca: „Wszyscy jesteśmy winni”. Jest to tylko inna wersja powiedzenia „nikt nie jest winien". Jeśli nikt nie jest winien, to nie warto rozważać sprawy w kategoriach dobra i zła. Formą dwuznacznego uniewinniania masowych mordów jest też powiedzenie: „Tak, te zamachy to niedobra rzecz, ale trzeba poznać przyczyny”. Jeśli powiedzenie „trzeba poznać przyczyny” znaczy to, co dosłownie znaczy, to jest to beztreściowy banał: oczywiście, cokolwiek się zdarza, ma przyczyny i dobrze jest je poznać. [...] Samo powiedzenie „trzeba poznać przyczyny” może i jest trywialnie słuszne wszechstosowalnie, ale zaczynając $\mathrm{z}$ tego miejsca, łatwo, bez dodatkowych wyjaśnień, przejść od „przyczyn” do racji i dalej - do dobrych racji. Czy to ma znaczyć, że dobre racje stają za wszystkim, włączając ludobójstwo hitlerowskie, czystki etniczne? ${ }^{52}$.

Jakże trafna uwaga, dotycząca także zła terroryzmu.

${ }^{50}$ Jan Paweł II, Pokój jest wartościa, która nie zna podziałów. Orędzie na Światowy Dzień Pokoju 1986, w: Orędzia Ojca Świętego Jana Pawła II, t. 1, Kraków 1998, nr 5.

${ }^{51}$ Franciszek, Adhortacja apostolska Evangelii gaudium, nr 238.

${ }^{52}$ Cztery małe traktaty, rozmowa z Leszkiem Kołakowskim, „Newsweek Polska” z dnia 23.02.2002, s. 48 . 


\section{BIBLIOGRAFIA}

Balthasar H. Urs von, Antico patto, Milano 1980.

Bastianel S., Di Pinto L., Per una fondazione biblica delletica, w: Corso di morale, red. T. Goffi, G. Piana, t. 1, Brescia 1983, s. 77-174.

Benedykt XVI, Adhortacja apostolska Sacramentum caritatis, Città del Vaticano 2007. Benedykt XVI, Adhortacja apostolska Verbum Domini, Città del Vaticano 2010.

Benedykt XVI, Encyklika Caritas in veritate, Città del Vaticano 2009.

Benedykt XVI, Wszyscy jesteśmy odpowiedzialni za sprawę pokoju. Przemówienie w bazylice Matki Bożej Anielskiej w Asyżu, 27.10.2011, „L'Osservatore Romano” 33 (2012) nr 1 s. 27-29.

Bosetti E., Il Figlio e i figli di Dio. Etica filiale del Nuovo Testamento, „Rivista di teologia morale" 36 (2004), s. 227-245;

Casabo Suqué J. M., La teología moral en San Juan, Madrid 1970, s. 127-129.

Colzani G., Antropologia teologica. L’uomo: paradosso e mistero, Bologna 1997.

Cottret M., Zabić tyrana? Tyranobójstwo w nowożytnej Europie, Warszawa 2012.

Curtis E.M., Image of God, w: The Anchor Bible Dictionary, t. 3, New York 1992, s. $389-391$.

Cztery małe traktaty, rozmowa z Leszkiem Kołakowskim, „Newsweek Polska” z dnia 23.02.2002.

Dziuba A.F., Kultura życia wobec kultury śmierci, „Collectanea Theologica” 84 (2014) nr 2, s. 93-105.

Dziuba A.F., Moralność i polityka. Razem czy oddzielnie?, „Sosnowieckie Studia Teologiczne" 12 (2015), s. 167-192.

Dziuba A.F., Paschalne obdarowanie Duchem Świętym, „Studia Gnesnensia” 28 (2014), s. 91-106.

Florenski P., La colonna e il fondamento della verità, Milano 1998.

Franciszek, Adhortacja apostolska Christus vivit, Città del Vaticano 2019.

Franciszek, Adhortacja apostolska Evangelii gaudium, Città del Vaticano 2013.

Franciszek, Adhortacja apostolska Gaudete et exsultate, Città del Vaticano 2018.

Franciszek, Encyklika Laudato si, Città del Vaticano 2015.

Franciszek, Encyklika „Lumen fidei”, Città del Vaticano 2013.

Guilluy P., Pardon et péché, w: Initiation à la pratique de la théologie, red. B. Lauret, F. Refoule, t. 4: Etique, Paris 1984, s. 249-294.

Jan Paweł II, Adhortacja apostolska Christifideles laici, Città del Vaticano 1988.

Jan Paweł II, Adhortacja apostolska Reconciliatio et paenitentia, Città del Vaticano 1984.

Jan Paweł II, Encyklika Evangelium vitae, Città del Vaticano 1995.

Jan Paweł II, Encyklika Redemptor hominis, Città del Vaticano 1979.

Jan Paweł II, Encyklika Sollicitudo rei socialis, Città del Vaticano 1987.

Jan Paweł II, Jeszcze raz potępiam terroryzm. Rozważanie przed modlitwa „Anioł Pański”, Watykan. 14.03.2004. „L'Osservatore Romano” 25 (2004) nr 6, s. 36.

Jan Paweł II, List apostolski Novo millennio ineunte, Città del Vaticano 2001. 
Jan Paweł II, Nie ma pokoju bez sprawiedliwości, nie ma sprawiedliwości bez przebaczenia. Orędzie na Światowy Dzień Pokoju 2002, „L'Osservatore Romano” 23 (2002) nr 2, s. 4-7.

Jan Paweł II, Nienawiść, fanatyzm i terroryzm znieważaja imię Boga. Spotkanie z przedstawicielami świata kultury, sztuki i nauki, Astana, 24.09.2001, „L'Osservatore Romano" 22 (2001) nr 11-12, s. 24-25.

Jan Paweł II, Pokój i pojednanie. Homilia wygłoszona w Drogheda, 29.09.1979, w: Jan Paweł II, Nauczanie papieskie, t. 2, cz. 2, red. E. Weron, A. Jaroch, Poznań 1992, s. 209-215.

Jan Paweł II, Pokój jest wartościa, która nie zna podziałów. Orędzie na Światowy Dzień Pokoju 1986, w: Orędzia Ojca Świętego Jana Pawła II, t. 1, Kraków 1998, s. 66-76.

Jan Paweł II, Poszanowanie mniejszości warunkiem pokoju. Orędzie na Światowy Dzień Pokoju 1989, Città del Vaticano 1988.

Jan Paweł II, Prawda i sprawiedliwość fundamentem wolności i pokoju. Audiencja generalna w pierwsza rocznice ataku terrorystycznego na USA, Watykan. 11.09.2002, „L'Osservatore Romano” 23 (2002) nr 10-11, s. 66.

Jan Paweł II, Zawsze aktualne zadanie: wychowywać do pokoju. Orędzie na Światowy Dzień Pokoju 2004, „L'Osservatore Romano” 25 (2004) nr 2, s. 4-7.

Jan Paweł II, Zło i śmierć nie maja ostatniego słowa. Przemówienie podczas audiencji generalnej, Watykan 12.09.2001, „L'Osservatore Romano” 22 (2001) nr 10, s. 66.

Katechizm Kościoła Katolickiego, Poznań 2002.

Kodeks Prawa Kanonicznego, Poznań 1984.

Ladaria L.F., Antropologia teologica, Roma - Casale Monferrato 1986.

Marchel W., Abba, Vater! Die Vaterbotschaft des Neuen Tataments, Düsseldorf 1963.

Negrier A., Léon-Dufour X., Brat, w: Słownik teologii biblijnej, red. X. Léon-Dufour, Poznań 1973, s. 104-107.

Papieska Rada Iustitia et Pax, Kompendium Nauki Społecznej Kościoła, Kielce 2005.

Schnackenburg R., L'esistenza cristiana secondo il Nuovo Testamento, Modena 1971, s. $43-46$.

Sobór Watykański II, Konstytucja duszpasterska o Kościele w świecie współczesnym Gaudium et spes, w: Sobór Watykański II, Konstytucje, dekrety i deklaracje, Poznań 2002, s. 526-606.

Targoński F., Morale biblica e teologia morale. Alcuni problemi concernanti l’applicabilità della morale biblica alla teologia morale di oggi, Roma 1982.

Tremblay R., L',innalzamento” del Figlio, fulcro della vita morale, Roma 2001.

Tremblay R., „Ma io vi dico...” L'agire eccellente, specifico della morale cristiana, Bologna 2005.

Tremblay R., Radicati e fondati nel Figlio. Contributo per una morale di tipo filiale, Roma 1997. 